\title{
Novel Cleaning Methodologies for Specimens Tested in Liquid Metals
}

\author{
Susumu HATAKEYAMA, Naoko OONO ${ }^{1)}$, Takashi NOZAWA ${ }^{2)}$, Kan SAKAMOTO ${ }^{3)}$, \\ Yoshie TAMAI ${ }^{4)}$ and Masatoshi KONDO ${ }^{4)}$ \\ Tokyo Institute of Technology, Department of Mechanical Engineering, Ookayama, Meguro-ku, Tokyo 152-8550, Japan \\ ${ }^{1)}$ Hokkaido University, Sapporo, Hokkaido 060-0808, Japan \\ 2) National Institutes for Quantum and Radiological Science and Technology, Rokkasho, Aomori 039-3212, Japan \\ ${ }^{3)}$ Nippon Nuclear Fuel Development, 2163 Narita-cho, Oarai-machi, Higashi-ibaraki-gun, Ibaraki 311-1313, Japan \\ 4) Tokyo Institute of Technology, Institute of Innovative Research, Ookayama, Meguro-ku, Tokyo 152-8550, Japan
}

(Received 8 December 2020 / Accepted 26 December 2020)

\begin{abstract}
Liquid metals are excellent coolants of fission and fusion reactors. However, the chemical compatibility of structural materials is important issue. The mass losses of the high-temperature materials such as FeCrAlODS, $\mathrm{SiC}$, and refractory metals by corrosion in liquid metals are essential information to obtain their corrosion rates. The specimens must be cleaned to remove liquid metals solidified and adhered on the specimens after the corrosion tests, though the damage of the specimens in the cleaning procedure must be minimized. Cleaning methodologies appropriate for the specimens tested in liquid metals are urgently required for further compatibility study. The cleaning methodology with $0.1 \mathrm{M}$ sodium hydroxide $(\mathrm{NaOH})$ solution was developed, in which $\mathrm{Sn}$ was selectively dissolved without any damage on the specimens of the high-temperature materials. The cleaning procedure to remove $\mathrm{Pb}, \mathrm{Bi}$, and these alloys (i.e., $\mathrm{Pb}-16 \mathrm{Li}$ and $\mathrm{Pb}-\mathrm{Bi}$ ) adhered on the specimens in the solution mixture of acetic acid, ethanol, and $\mathrm{H}_{2} \mathrm{O}_{2}$ were also studied.
\end{abstract}

(c) 2021 The Japan Society of Plasma Science and Nuclear Fusion Research

Keywords: liquid metal, cleaning procedure, compatibility study, corrosion

DOI: $10.1585 / \mathrm{pfr} .16 .1205015$

Liquid tin (Sn) is a candidate coolant of liquid surface divertor concepts [1]. The chemical compatibility of liquid Sn with structural materials is one of the important issues to be addressed. FeCrAl alloys and $\mathrm{SiC}$ are the candidate structural and functional materials. Alumina $\left(\mathrm{Al}_{2} \mathrm{O}_{3}\right)$ protective layers formed on the surface of $\mathrm{FeCrAl}$ alloys were effective to mitigate the corrosion in liquid Sn [2]. US/Japan joint research project FRONTIER has started [3], and the corrosion resistance of FeCrAl alloys and other materials in liquid $\mathrm{Sn}$ under neutron irradiation is going to be studied.

The corrosion rate is one of the essential parameters not only for the investigations on corrosion behaviors but also for the design of liquid divertor systems. The corrosion rate can be obtained from the mass loss of the specimen due to its corrosion in the liquid metals. The corrosion tests of Mo and W were performed in liquid Sn, and the adherence of $\mathrm{Sn}$ on their specimens was removed by the cleaning process using liquid lithium (Li) [4]. However, this cleaning method cannot be applied for $\mathrm{SiC}$ and $\mathrm{FeCrAl}$ alloys protected by $\mathrm{Al}_{2} \mathrm{O}_{3}$ layer, since they are thermodynamically unstable and chemically corroded and damaged in liquid $\mathrm{Li}$ [5]. Liquid lithium lead alloy (Pb-16Li) is a promising liquid breeder of fusion reactors. Lead $(\mathrm{Pb})$ and
Lead bismuth eutectic $(\mathrm{Pb}-\mathrm{Bi})$ are considered as a coolant of Generation four (GIF) fast reactors (FRs). The specimens tested in liquid $\mathrm{Pb}$ alloys were cleaned with the solution mixture of acetic acid, ethanol, and $\mathrm{H}_{2} \mathrm{O}_{2}$ solution $(1: 1: 1)$ in the previous studies [6,7]. However, the effect of the solution on the $\mathrm{SiC}$ and $\mathrm{FeCrAl}$ alloys has to be clarified.

Appropriate cleaning methodologies for the specimen tested in liquid metals are urgently required. The purpose of the present study is to develop the cleaning methodologies for further liquid metal compatibility studies.

Dissolving behaviors of solidified liquid metals (i.e., $\mathrm{Sn}, \mathrm{Pb}, \mathrm{Bi}, \mathrm{Pb}-16 \mathrm{Li}$, and $\mathrm{Pb}-\mathrm{Bi}$ ) in chemical solutions were investigated by means of dissolution tests. The solidified Sn specimen was immersed in $0.1 \mathrm{M} \mathrm{NaOH}$ solution $(160 \mathrm{cc})$ at $60^{\circ} \mathrm{C}$. The specimens of hightemperature materials (i.e., Kanthal APMT (Fe-21Cr-5Al3Mo), NF12 (Oxide dispersion strengthened alloys alloy (ODS), Fe-12Cr-6Al-0.4Zr-0.47 $\left.\mathrm{Y}_{2} \mathrm{O}_{3}-0.24 \mathrm{Ex} . \mathrm{O}\right), 430$ (Fe-18Cr), and CVD-SiC (fabricated by Rohm\&Haas Co, Purity: 99.9995\% [8])) were also separately tested. The specimen size of solidified liquid metals were approximately $\phi 20 \times 2 \mathrm{~mm}$, that of APMT and SiC were $10 \mathrm{~mm}$ $\times 15 \mathrm{~mm} \times 2 \mathrm{~mm}$, and that of NF12 was $6 \mathrm{~mm} \times 17 \mathrm{~mm}$ $\times 1 \mathrm{~mm}$. The specimens of APMT and NF12 were pre- 


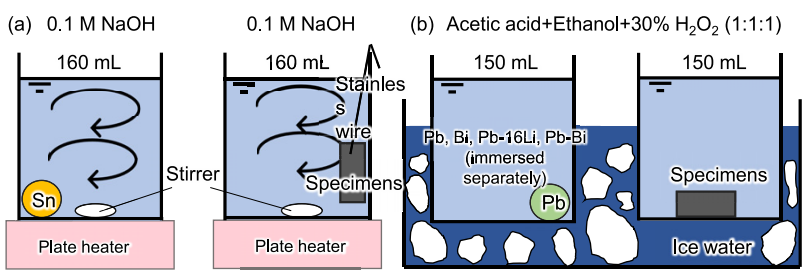

Fig. 1 (a) Immersion of $\mathrm{Sn}$ and high temperature materials in $0.1 \mathrm{M} \mathrm{NaOH}$ solution, (b) Immersion of $\mathrm{Pb}$ alloys in the solution of mixture of acetic acid, ethanol, and $30 \% \mathrm{H}_{2} \mathrm{O}_{2}$ $(1: 1: 1)$.

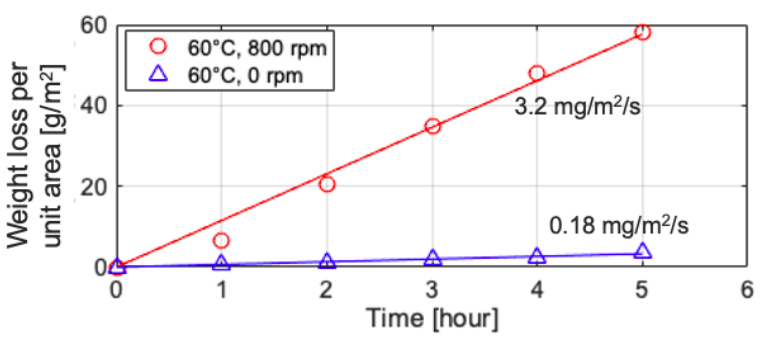

Fig. 2 Dissolution of $\mathrm{Sn}$ in $0.1 \mathrm{M} \mathrm{NaOH}$ at static and mixing flow conditions.

oxidized at $1000^{\circ} \mathrm{C}$ for 10 hours before the immersion, and their surface were covered by $\alpha-\mathrm{Al}_{2} \mathrm{O}_{3}$ oxide layer. The temperature of the solution was kept at $333 \mathrm{~K}$ using a plate heater. The dissolution tests were performed at a static and a mixing flow condition. The mixing flow was made by a rotating magnetic stirrer with the rotational speed of $800 \mathrm{rpm}$ as shown in Fig. 1 (a). The specimens were taken out from the solution after the tests, and cleaned with ethanol. The mass losses of the Sn specimen in the solution are summarized in Fig. 2. Sn dissolved in the alkali solution and its rate was $1.8 \times 10^{-4} \mathrm{~g} / \mathrm{m}^{2} / \mathrm{s}(0.090 \mu \mathrm{m} / \mathrm{h})$ in the static condition. The dissolution rate of $\mathrm{Sn}$ in the mixing flow $(800 \mathrm{rpm})$ was $0.0032 \mathrm{~g} / \mathrm{m}^{2} \mathrm{~s}(1.57 \mu \mathrm{m} / \mathrm{h})$. The dissolution of $\mathrm{Sn}$ in the solution is expressed as [9],

$$
\mathrm{Sn}+0.5 \mathrm{O}_{2}+\mathrm{OH}^{-} \rightarrow \mathrm{HSnO}_{2}^{-} \text {. }
$$

Oxygen in air atmosphere dissolved into the solution mixture, and might contribute the chemical reaction in Eq. (1). Finally, $\mathrm{HSnO}_{2}{ }^{-}$was dissolved in the solution. The mass losses of the APMT, NF12, and SiC specimens by the immersion to the solution for 6 hours were in the range between $0.27 \mathrm{~g} / \mathrm{m}^{2}$ and $-1.08 \mathrm{~g} / \mathrm{m}^{2}$ (mass gain). These values were negligibly small rather than the mass losses of the specimens by the corrosion in liquid Sn [10].

Figure 3 shows the cleaning procedures of the 430 specimen immersed in liquid $\mathrm{Sn}$ at $773 \mathrm{k}$ for 250 hours. Solid $\mathrm{Sn}$ adhered on the specimen dissolved little by little in the $0.1 \mathrm{M} \mathrm{NaOH}$ solution at $333 \mathrm{~K}$ and $800 \mathrm{rpm}$ as indicated with solid line in Fig. 3. The dissolution rate of Sn adhered on the 430 specimen was $7.5 \mathrm{mg} / \mathrm{m}^{2} / \mathrm{s}$ and it was larger than that obtained for the solidified Sn specimen

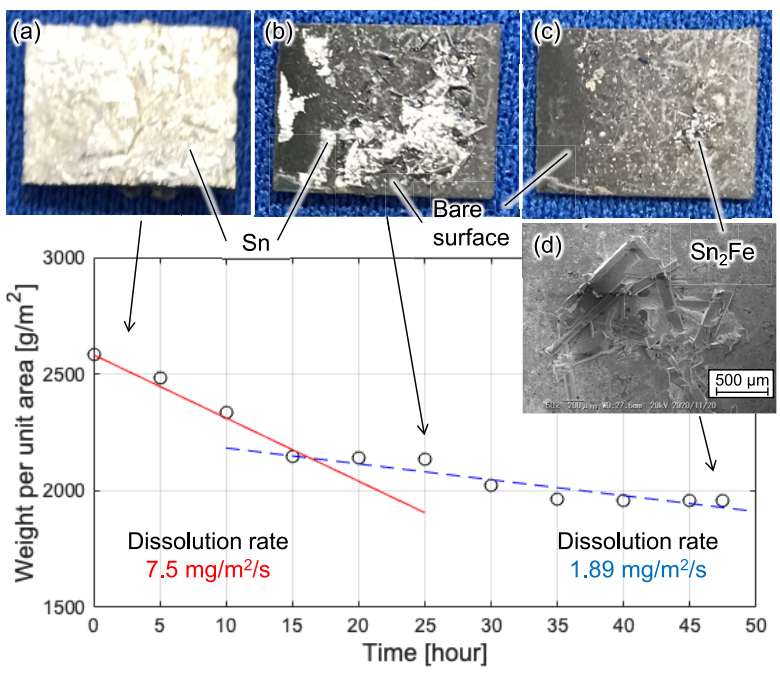

Fig. 3 Cleaning process of 430 specimen in $0.1 \mathrm{M} \mathrm{NaOH}$ solution at $333 \mathrm{~K}$ and $800 \mathrm{rpm}$, (a) after test in liquid $\mathrm{Sn}$ at $773 \mathrm{~K}$ for 250 hours, (b) after immersion in solution for 25 hours, (c) after immersion in solution 50 hours, and (d) SEM image of $\mathrm{Sn}_{2} \mathrm{Fe}$ needle-like substance on specimen surface.

described above $\left(3.2 \mathrm{mg} / \mathrm{m}^{2} / \mathrm{s}\right)$. The dissolution of $\mathrm{Sn}$ adhered on the 430 specimen was promoted due to its rough and large surface area. The intermetallic compounds of $\mathrm{FeSn}$ and $\mathrm{FeSn}_{2}$ [9] formed on the specimen surface. The dissolution rate of these compounds was lower than that of pure $\mathrm{Sn}$ as indicated by dotted line in Fig. 3. The specimen was totally cleaned in two days, though few needle-like substances of $\mathrm{FeSn}_{2}$ remained on the specimen. The thickness of solid Sn adhered on steels after the corrosion tests is typically $50 \mu \mathrm{m}$, though the adherence on the high temperature materials are much less than that on the steels. Therefore, the cleaning of specimens can be completed within a few days.

Figure 1 (b) shows the experimental set up for the dissolution tests with the specimens of $\mathrm{Pb}$ alloys and the composition elements in the solution of mixture of acetic acid, ethanol, and $30 \% \mathrm{H}_{2} \mathrm{O}_{2}(1: 1: 1)$. This solution has been used to dissolve $\mathrm{Pb}-16 \mathrm{Li}[6]$ and $\mathrm{Pb}-\mathrm{Bi}$ [7] adhered on the specimens. The solution was installed in an ice water bath. The test duration was in the range between 5 and 20 minutes. The temperature of the tests with $\mathrm{Pb}$ $\mathrm{Bi}$ and $\mathrm{Bi}$ samples was $5^{\circ} \mathrm{C}$. The solution temperature in the tests performed with of $\mathrm{Pb}, \mathrm{Sn}$, and $\mathrm{Pb}-17 \mathrm{Li}$ specimens was $15^{\circ} \mathrm{C}$ because of the heat generation of the chemical reactions. The specimens were taken out from the solution and cleaned with ethanol.

Figure 4 shows the mass losses of $\mathrm{Pb}, \mathrm{Bi}, \mathrm{Sn}, \mathrm{Pb}-16 \mathrm{Li}$, and $\mathrm{Pb}-\mathrm{Bi}$ in the solution. In this acetic acid mixture solution, $\mathrm{Pb}$ and $\mathrm{Bi}$ dissolved as,

$$
\begin{array}{r}
2 \mathrm{~Pb}+\mathrm{O}_{2}+4 \mathrm{CH}_{3} \mathrm{COOH} \rightarrow \\
2 \mathrm{~Pb}\left(\mathrm{CH}_{3} \mathrm{COO}\right)_{2}+2 \mathrm{H}_{2} \mathrm{O},
\end{array}
$$




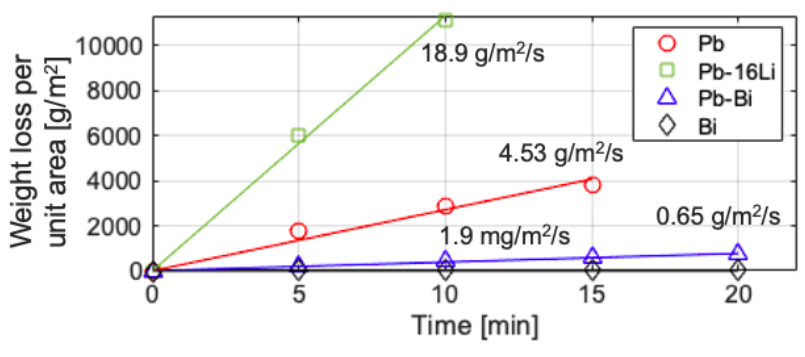

Fig. 4 Mass loss of $\mathrm{Pb}, \mathrm{Pb}-16 \mathrm{Li}, \mathrm{Pb}-\mathrm{Bi}$, and $\mathrm{Bi}$ in acetic acid mixture solution.

$$
\begin{gathered}
4 \mathrm{Bi}+3 \mathrm{O}_{2}+12 \mathrm{CH}_{3} \mathrm{COOH} \rightarrow \\
4 \mathrm{Bi}\left(\mathrm{CH}_{3} \mathrm{COO}\right)_{3}+6 \mathrm{H}_{2} \mathrm{O} .
\end{gathered}
$$

were $4.53 \mathrm{~g} / \mathrm{m}^{2} \mathrm{~s}(1437 \mu \mathrm{m} / \mathrm{hr}), 18.9 \mathrm{~g} / \mathrm{m}^{2} \mathrm{~s}(6670 \mu \mathrm{m} / \mathrm{hr})$, $0.65 \mathrm{~g} / \mathrm{m}^{2} \mathrm{~s}(230 \mu \mathrm{m} / \mathrm{hr})$, and $0.0019 \mathrm{~g} / \mathrm{m}^{2} \mathrm{~s}(0.69 \mu \mathrm{m} / \mathrm{hr})$, respectively. Sn did not dissolve in the mixture solution. The mass losses of the APMT, NF12, and SiC specimens by the immersion to the solution were negligibly small.

[1] R.E. Nygren et al., Mater. Energy 9, 6 (2016).

[2] M. Kondo et al., Fusion Eng. Des. 146, 2450 (2019).

[3] Y. Hatano et al., J. Plasma Fusion Res. 96, 3, 145 (2020).

[4] N. Kawano et al., Plasma Fusion Res. 15, 1205068 (2020).

[5] T. Yoneoka et al., Mater. Trans. 42, No.6, 1019 (2001).

[6] M. Kondo et al., Fusion Eng. Des. 87, 1777 (2012).

[7] S. Saito et al., JAERI-Tech 2004-074 (2004).

[8] L.L. Snead et al., J. Nucl. Mater. 371, 329 (2007).

[9] S. Uchida et al., J. Japan Inst. Metals 60, No.9, 826 (1996). [10] M. Kondo et al., Fusion Eng. Des. 98-99, 2003 (2015).

The dissolution rate of $\mathrm{Pb}, \mathrm{Pb}-16 \mathrm{Li}, \mathrm{Pb}-\mathrm{Bi}$, and $\mathrm{Bi}$ 